\title{
The Role of Corporate Governance in Firm Performance
}

\author{
Zahroh Naimah ${ }^{1, *}$, and Hamidah ${ }^{1}$ \\ ${ }^{1}$ Accounting Department, Faculty of Economics and Business, Universitas Airlangga, Indonesia
}

\begin{abstract}
The objective of this study is to examine the role of corporate governance to increase firm performance. The measure of corporate governance are corporate governance mechanism and Corporate Governance Perception Index (CGPI). Samples are companies that followed CGPI award at 2005-2014. The examination of the relationship of corporate governance and firm performance is conducted by regression of corporate governance mechanism variables and control variables to profitability. Corporate governance mechanisms are board size, board independence, outside directors, audit committee size, audit committee meeting, audit quality, and CGPI. Control variables are leverage and firm size. The results of this study indicate that board independence negatively influence profitability, audit committee meeting positively influence profitability, audit quality positively influence profitability, CGPI positively influence profitability, leverage negatively influence profitability, and firm size negatively influence profitability.
\end{abstract}

\section{Introduction}

Corporate governance is commonly understood as the way and practice to directing, organizing, and control the company. Corporate governance is the system designed to professionally direct the company based on good corporate governance principles. Good corporate governance principles are transparency, accountability, responsibility, independence, and fairness.

The practice of corporate governance is strongly influenced by the parties involved in the management system of a company such as shareholders, investors, creditors, employees, and government. Good corporate governance is expected to increase firm performance. The main objective of the implementation of good corporate governance is to optimize value for shareholders and stakeholders in the long run.

This research tries to prove that corporate governance that is performed well can improve firm performance. Generally, this study is aimed to examine whether corporate governance mechanisms and principles influence firm performance. Specifically, the objectives of this study are examine the influence of board size, board independence, outside directors, audit committee size, audit committee meeting, audit quality, and corporate governance principles to firm performance.

\footnotetext{
* Corresponding author: zahrohnaimah@yahoo.com
} 


\section{Literature Review}

\subsection{Corporate Governance}

Cadbury Report defines corporate governance as "a system in which companies are directed and controlled" [1]. The board of directors is responsible for the implementation of corporate governance. The role of shareholders in governance is to appoint directors and auditors, and ensuring that the directors and the auditor has run the appropriate governance structure. While the auditor's role in providing an assessment of the financial statements presented by management.

Corporate governance mechanisms include institutional ownership in the company, stock ownership by directors and executive officers, board of directors characteristics, age and tenure of the CEO, and the sensitivity of CEO pay-for-performance [2].

Institutional investors in large numbers will have the opportunity, resources, and ability to monitor and influence the manager. Shares and/or options ownership by directors and executive officers will encourage behavior that can increase the value of the firm, but will also encourage managers to use discretionary accruals to increase firm performance in the period around the sale of shares or the use of options, so as to improve the welfare of directors and the executive officer [2]. Directors appointed to manage and control the business of the company. As an agent of the company and its shareholders, directors must protect the interests of shareholders as the owner of the company. Characteristics of the board of directors can be measured by the percentage of independent directors (outside directors), CEO duality, and the size of the board. Age and tenure of CEO influence the effectiveness in managing the company. The older or the longer the tenure of the CEO, the deeper understanding of the CEO of the company and industry, and improve the performance of the company [2].

\subsection{Corporate Governance and Firm Performance}

P.A. Gompers, L. Ishii, and A. Metrick found a strong correlation between corporate governance and stock returns throughout 1990 and firm value, as measured by Tobin's Q [3]. L.D. Brown and M.L. Caylor found that companies that are managed better would be more profitable, more valuable, and to pay more cash dividends to shareholders [4].

Managers tend to expropriate the company's assets and work on projects that benefit themselves personally [5]. Effective corporate governance that reduces 'right to control' of shareholders and creditors given to managers, increasing the probability that managers invest in projects that generate net positive present value [6]. This shows that companies that are managed better have a better operational performance, the performance measures used by L.D. Brown and M.L. Caylor [4]. Empirically, R. La Porta, F. Lopex-de-Silanes, A. Shleifer, and R. Vishny indicate that investor protection associated with effective corporate governance [7].

\subsubsection{Board size and firm performance}

There are two opposing ideas on the relationship between board size and firm performance. First, thought that the lesser the board size can greatly contribute to the company's success. D. Yermack found an inverse relationship between board size with company's value and favorable financial ratios such as profitability, asset utilization, and Tobin's Q [8]. Empirical evidence of S. Cheng showed that companies that have more board members, the variability of the firm performance would be lower [9]. 
The second thought argued that a large board size will increase the firm performance. Board size is a determinant of the ability of directors to monitor and control manager. R. Adam and H. Mehran argued that the company should have a large board size to be able to monitor effectively [10]. Large board size will support a more effective management of the company [11]. Large board size will be easier to obtain information [12].

Hypothesis 1: Board size influence firm performance

\subsubsection{Board independence and firm performance}

Previous studies of the relationship between the independence of directors and firm performance, showed inconsistent results. The higher the proportion of outsider, the more independent board of directors [13]. S. Bhagat and B. Black found no association between proportion of outsider and Tobin's Q, ROA, asset turnover, and stock returns [14].

The composition of board of directors plays an important role in determining the firm financial performance. Board of directors is authorized to monitor managerial activities, evaluate the performance of managers, and give awards to the manager. According to E.F. Fama and M.C. Jensen, board of directors is an internal control mechanism that is essential for monitoring top management [15].

S. Rosenstein and J. Wyatt found a market award to the company that has the outsider [16]. J. Brickley, J. Coles, R. Terry found a positive relationship between the proportion of outsider by the reaction of stock market [17]; and R. Anderson, S. Mansi, and D. Reeb found the opposite relationship between independence of directors and cost of debt [18]. A large number of board and a large proportion of outsider can provide great information. Several studies have found that board size and the proportion of outsider positively related to firm size and complexity [19].

L.D. Brown and M.L. Caylor found no relationship between the independence of directors and Tobin's Q, but found a positive relationship between the independence of directors and ROE, profit margin, dividend yield, and stock repurchases [4]. They found that the company would be worth if the position between the CEO and the board are separated. S. Rosenstein and J. Wyatt found evidence that shareholder value is influenced by the proportion of outside directors as indicated by the positive stock price reaction during the announcement of the appointment of outside directors [16].

Hypothesis 2: Board independent influence firm performance

Hypothesis 3: Outside directors influence firm performance

\subsubsection{Audit committee and firm performance}

Audit committee as a committee plays an important role in ensuring and monitoring the accounting process so that management can provide information that is relevant and credible to all stakeholders [20]. The existence of audit committee independence is able to provide reliable accounting information, so audit committee independence is expected to improve the company's performance. L.D. Brown and M.L. Caylor found that independent audit committee positively related to dividend yield [4].

The 1999 Blue Ribbon Committee Report recommends that audit committee, as supervisor of financial accounting processes, conduct meetings at least four times a year in order to guarantee the quality of financial reporting [21]. If audit committee size and audit committee meeting frequency can improve financial accounting process, it is expected that audit committee size and meetings frequency can improve firm performance.

Hypothesis 4: Audit committee size influence firm performance

Hypothesis 5: Audit committee meetings influence firm performance 


\subsubsection{Audit quality and firm performance}

Audit quality as a means of monitoring corporate governance from the outside, can improve firm performance. The study results proved that large auditors have a good reputation which reflects the good quality than smaller auditor [22]. Z.V. Palmrose suggest that the big- 8 auditors audit charge high fees because of high audit quality [23]. A. Martinez, and A. de Jesus Moraes found that auditors imposes higher audit fees will give a signal to markets that high audit quality may enhance shareholder value [24].

Hypothesis 6: Audit quality influence firm performance

\subsubsection{Corporate governance principles and firm performance}

The principles of corporate governance consists of transparency, accountability, responsibility, independence and fairness. IICG (The Indonesian Institute for Corporate Governance) create a corporate governance index, known as Corporate Governance Perception Index (CGPI). Implementation of good corporate governance is expected to improve the company's performance [25].

Hypothesis 7: Corporate Governance Principles influence firm performance

\section{Methodology}

The study period covers 10 years, $\mathrm{t}=2005$ to 2014 . The samples were all companies registered for the Corporate Governance Perception Index (CGPI). Data was obtained from secondary data that are CGPI and financial data operiod of 2005-2014.

The independent variables is corporate governance mechanism and Corporate Governance Perception Index (CGPI). Corporate governance mechanisms include number of board of directors (BoSize), number of independent board (BoInd), number of outside directors (OutDir), umber of audit committee (AcSize), frequency of audit committee meetings in a year (AcMeet), and audit quality (Audit). The dependent variable is firm performance as measured by profitability. Measures of profitability is return on assets (ROA). This study also incorporate leverage (LEV) and firm size (SIZE) as control variables.

The examination of the influence of corporate governance on firm performance is done by multiple regression test:

$$
\begin{aligned}
& \text { PROF }_{\text {it }}=\alpha_{0}+\alpha_{1} \text { BoSize }_{\mathrm{it}-1}+\alpha_{2} \text { BoInd }_{\mathrm{it}-1}+\alpha_{3} \text { OutDir }_{\mathrm{it}-1}+\alpha_{4} \text { AcSize }_{\mathrm{it}-1}+\alpha_{5} \text { AcMeet }_{\mathrm{it}-1} \\
& +\alpha_{6} \mathrm{AUDIT}_{\mathrm{it}-1}+\alpha_{7} \mathrm{CGPI}_{\mathrm{it}}+\alpha_{8} \mathrm{LEV}_{\mathrm{it}-1}+\alpha_{9} \mathrm{SIZE}_{\mathrm{it}-1}+\varepsilon_{\mathrm{it}}
\end{aligned}
$$

where PROF is profitability.

\section{Results}

The samples were all over the listed company (listed on the Indonesia Stock Exchange) listed as participants of Corporate Governance Perception Index (CGPI) in 2005-2014. Data collection are 133 observations.

Table 1 below is an overview of the results of hypothesis testing. Results shows that board independence negatively influence firm profitability. This shows that the independent board will potentially reduce the profitability of the company. These results are not consistent with previous studies that show that board independence will increase the company's performance. Results of previous studies have not been consistent on the association of board independence and corporate performance.

The number of audit committee meetings is found positively influence firm profitability. This shows that the more frequent audit committee meetings, the higher 
profitability of the company. The audit committee oversees the ongoing accounting procedures so that management can provide information that is relevant and credible to all stakeholders [20]. More frequent audit committee meetings is expected to improve firm performance. These results are consistent with L.D. Brown and M.L. Caylor were shown a link between audit related governance factors and firm performance [4].

Table 1. The association of corporate governance and profitability

\begin{tabular}{|l|c|l|l|l|}
\hline \multicolumn{1}{|c|}{ Variable } & Prediction & \multicolumn{1}{c|}{ Coefficient } & \multicolumn{1}{c|}{ t-statistic } & Prob-value \\
\hline Constant & No & 36.13970 & 2.317005 & 0.0221 \\
\hline BoSize & + & 0.428252 & 1.091527 & 0.2771 \\
\hline BoInd & + & -0.116002 & -2.209253 & 0.0289 \\
\hline OutDir & + & 0.015278 & 0.510375 & 0.6107 \\
\hline ACSize & + & 0.329015 & 0.686524 & 0.4936 \\
\hline ACMeet & + & 0.107269 & 1.991949 & 0.0485 \\
\hline AUDIT & + & 5.877332 & 3.193858 & 0.0018 \\
\hline CGPI & + & 0.473773 & 3.169802 & 0.0019 \\
\hline LEV & - & -0.139464 & -5.132474 & 0.0000 \\
\hline SIZE & + & -4.982884 & -3.180228 & 0.0018 \\
\hline
\end{tabular}

Audit quality is found have positive effect on firm profitability. Audit quality as a means of monitoring the implementation of corporate governance from the outside, can improve firm performance, consistent with A. Ferguson and D. Stokes [22]. Big Auditor has a good reputation and produce good audit quality, so as to improve firm performance.

Corporate Governance Perception Index (CGPI) is found positively influence firm profitability. This indicates that the implementation of good corporate governance will increase firm profitability, consitent with F. Siagian, S.V. Siregar, and Y. Rahadian that found that GCG practice positivelly affect firm value [26]. Implementation of good corporate governance is expected to improve firm performance the firm is managed transparently and accountable.

\section{Conclusion}

The results indicates that board size does not significantly influence profitability. Board independence significantly have negative effect on profitability. Outside director found not to significantly affect profitability. Audit committee size did not significantly affect profitability. The number of audit committee meetings significantly have positive effect on profitability. Audit quality significantly have positive effect on profitability. The principles of corporate governance significantly have positive effect on profitability. Leverage and firm size have negative effect on profitability.

\section{References}

1. Cadbury Report, (London: London Stock Exchange, 1992).

2. M.M. Cornett, A.J. Marcus, H. Tehranian, Journal of Financial Economics, 87, 357$373(2008)$

3. P.A. Gompers, L. Ishii, A. Metrick, Quarterly Journal of Economics, 118(1), (2003)

4. L.D. Brown, M.L. Caylor, Working Paper, Georgia State University (2004)

5. C.M. Jensen, H.W. Meckling, Journal of Financial Economics, 3, 305-360 (1976)

6. A. Shleifer, R. Vishny, Journal of Finance, 2, 737-783 (1997)

7. R. La Porta, F. Lopex-de-Silanes, A. Shleifer, R. Vishny, Journal of Financial Economics, 58, 3-27 (2000) 
8. D. Yermack, Journal of Financial Economics, 40, 185-211 (1996)

9. S. Cheng, Journal of Financial Economics, 87, 157-176 (2008)

10. R. Adam, H. Mehran, Working Paper. Federal Reserve Bank of New York (2002)

11. A. Klein, Journal of Law and Economics, 41(1), 275-303 (1998)

12. D.R. Dalton, C.M. Daily, J. Jonhson, A.E. Ellstrand, The Academy of Management Journal, 42(6), 674-686 (1999)

13. K. John, L.W. Senbet, Journal of Banking \& Finance, 22, 371-403 (1998)

14. S. Bhagat, B. Black, Journal of Corporation Law, 27, 231-274 (2002)

15. E.F. Fama, M.C. Jensen, Journal of Law and Economics, 26, 301-325 (1983)

16. S. Rosenstein, J. Wyatt, Journal of Financial Economics, 26, 175-191 (1990)

17. J. Brickley, J. Coles, R. Terry, Journal of Financial Economics, 35, 371-390 (1994)

18. R. Anderson, S. Mansi, D. Reeb, Journal of Accounting and Economics, 37, 315-342 (2004)

19. K. Lehn, P. Sukesh, M. Zhao, Working Paper, Katz Graduate School of Business, (2003)

20. M. Beasley, Accounting Review, 71, 443-465 (1996)

21. Blue Ribbon Committee on Improving the Effectiveness of Corporate Audit Committees (1999)

22. A. Ferguson, D. Stokes, Contemporary Accounting Research. 19(1), 77-110 (2002)

23. Z.V. Palmrose, Journal of Accounting Research, 24(1), 97-110 (1986)

24. A. Martinez, A. de Jesus Moraes, Journal of Modern Accounting and Auditing, 10(4), 442-450 (2014)

25. The Indonesian Institute for Corporate Governance, Laporan Program Riset dan Pemeringkatan Corporate Governance Perception Index 2014. (The Indonesian Institute for Corporate Governance, 2015).

26. F. Siagian, S.V. Siregar, Y. Rahadian, Journal of Accounting in Emerging Economies 3(1), 4-20 (2013). 